\title{
DESIGN OF UPVC THIN CORRUGATED ROOFING SHEET FOR INDONESIAN
}

\section{MARKET}

\author{
DJOKO SETYANTO ${ }^{1}$, ARKA DWINANDA SOEWONO ${ }^{2}$ \& WIDODO WIDJAJA BASUKI ${ }^{3}$ \\ ${ }^{I}$ Associate Professor, Department of Mechanical Engineering, Faculty of Engineering, Atma Jaya Catholic \\ University of Indonesia, Indonesia \\ ${ }^{2,3}$ Assistant Professor, Department of Mechanical Engineering, Faculty of Engineering, Atma Jaya Catholic \\ University of Indonesia, Indonesia
}

\begin{abstract}
Corrugated roofing sheet from Unplasticized Polyvinyl Chloride (UPVC) material has good prospects in Indonesia. The advantage of UPVC material is corrosion resistant, lightweight, not easily broken and economic. This paper describes the design of thin corrugated roofing sheet from UPVC material. The design includes determining the shape of the roof profile and its strength as a roof structure. Flammability properties, tensile strength and modulus of elasticity of roofing material are obtained from flammability and tensile tests of the roof sample. Roof production is carried out using an extrusion injection molding machine in a manufacturing plant at Tangerang, Indonesia. The result of the design is a corrugated thin roofing sheet from UPVC material with an effective roof width of $750 \mathrm{~mm}$ which has five crests and four valleys.

KEYWORDS: UPVC, Corrugated Roof, Roof Design, Sheet
\end{abstract}

Received: Mar 17, 2020; Accepted: Apr 07, 2020; Published: May 18, 2020; Paper Id.: IJMPERDJUN202051

\section{INTRODUCTION}

Corrugated roofing sheets, commonly used throughout the world for industrial, commercial and other buildings are made of metals. Metal materials that are widely used for roofing sheets are steel and aluminum. The steel sheet material for the roof is usually coated with zinc and aluminum alloys (55\% $\mathrm{Al}-\mathrm{Zn}$ ) for corrosion protection layer. The disadvantage of this type of roof in the application for factory and warehouse buildings on the coastal and other corrosive areas such as fertilizer factory is the degradation of the material due to corrosion [1-3]. In Indonesia, metal roofing sheets are available in various types of profiles and price, depending on the thickness of the roof and the protective layer.

Corrugated roofing sheets that are more economical than metal roofs are made of fiber reinforced mortar composites [4]. The reinforcing fibers commonly used are asbestos, glass fiber, and natural fiber [5, 6]. The main weakness of the mortar roof is its extra weight, brittleness due to its impact, hazard potential, and relatively short durability. On the other hand, it has the advantage of resistance to corrosion [7-11].

In order to reduce the weaknesses of metal and mortar roofing sheets, they are filled with polymeric material. The advantage of the polymeric materials are light weight, not easily broken, sound absorption, and resistant to corrosion [12-14].

In Indonesia, polymeric roofing sheet materials, particularly Glass Fiber Reinforced Polymer (GFRP), have been widely used in factories and warehouse buildings located in corrosive areas since 2008 [15]. The main 
drawback of the GFRP roof are low resistance to fire and relative expensive. This deficiency can be mitigated by using Rigid Polyvinyl Chloride or Unplasticized Polyvinyl Chloride (UPVC). The UPVC provides benefit in terms of lower price and higher resistance to fire than GFRP materials [16].

In Indonesian market, hollow corrugated roofing sheets from UPVC material are avalable for more than five years. The hollow roofing sheets price is still more expensive than the price of metal roofing sheets and hence marketing is still limited [17]. These deficiencies can be filled by corrugated roofing sheets from UPVC solid material which is lighter and provides more economical value than hollow roofing sheets.

The advantages of the roofing sheets from UPVC material are corrosion resistant, fire retardant, noise insulation, lightweight, durable and reasonably price competitive. Furthermore, selection of grey color similar to the color of metal roofing sheet will result in cooler roof temperature since it has higher ability to reflect sunlight. This is supported by research studies on reducing the heat gains of corrugated roofing sheets made of aluminum and galvanized steel conducted by Kic and Müller [18]; and a study of highly reflective roofing sheets by Yuan et al [19] and Uemoto et al [20]. The selection of fillers and additives in a mixture of PVC resin in the right amount will provide sufficient strength and rigidity as a roof structure against loads from wind and rain. The study of the strength of corrugated roofing sheets when receiving static and dynamic wind force, whether thrust or lift and cyclone wind forces have been carried out by Koshy and Arul Jayachandran [21] and Narayan and Mathews [22-24]. These studies can be used as a reference for designing solid roofing sheets from UPVC material that will be aimed at increasing market opportunities in Indonesia. This paper describes the design of thin corrugated roofing sheets from UPVC material.

\section{METHOD}

The design process is illustrated in Figure 1. The Product Design Specification (PDS) of the solid thin corrugated roofing sheets from UPVC material contains technical requirements of the roof designer. In parallel, flammability and tensile tests of the UPVC material samples are carried out to get flammability properties, tensile strength and modulus of elasticity based on UL 94 and ASTM D638 standards. The specimen and equipment for tensile and flammability tests are shown in Figure 2.

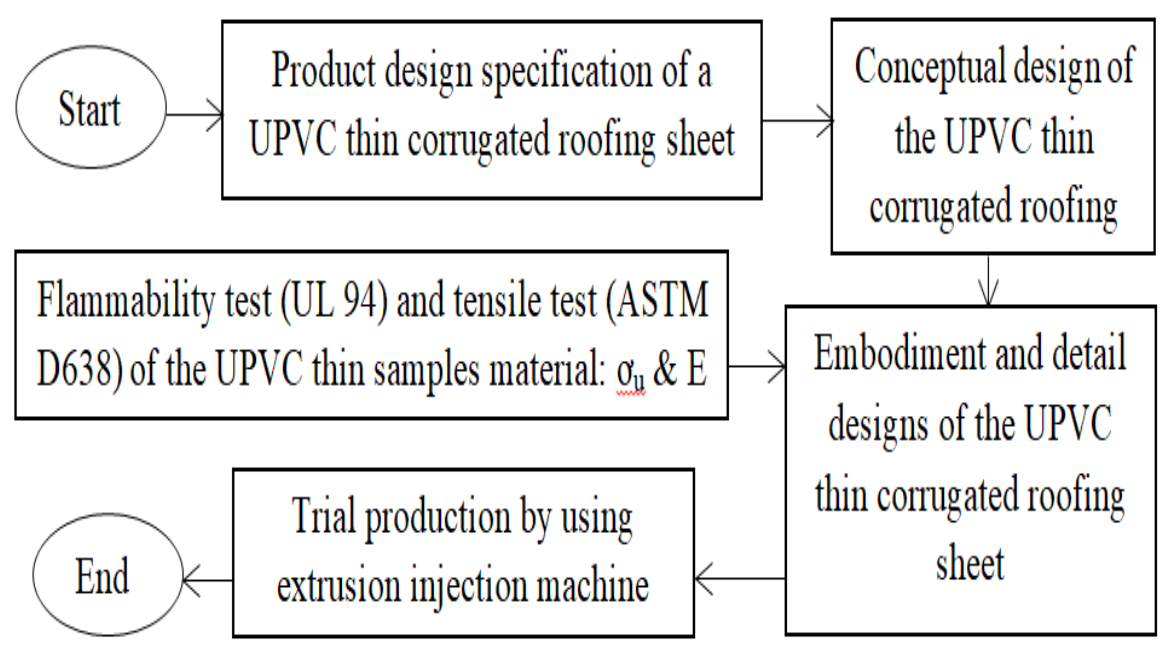

Figure 1: Design Process of the UPVC Thin Corrugated Roofing Sheet. 


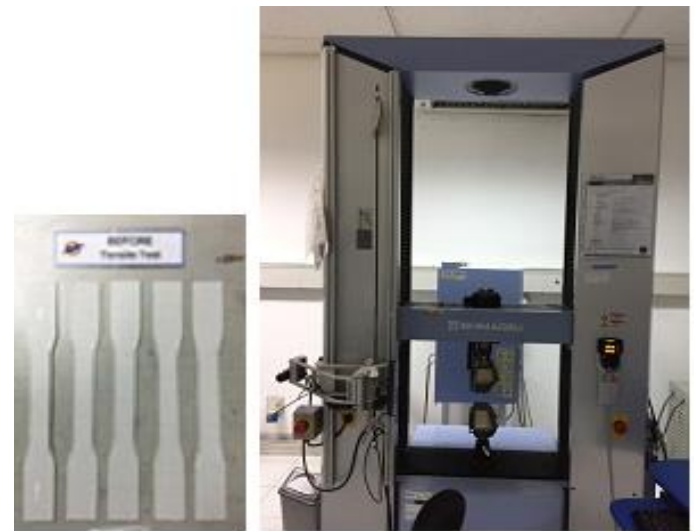

(a)

(b)

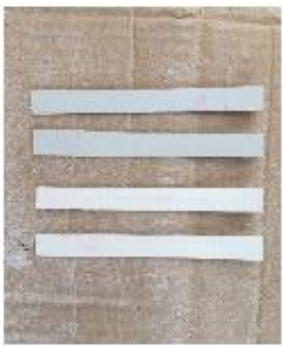

(c)

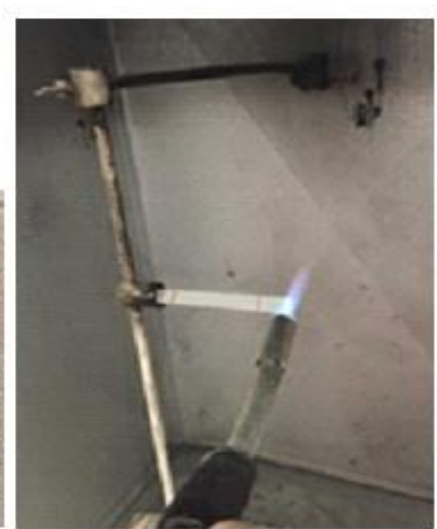

(d)

Figure 2: Tensile and Flammability Test Specimens and Equipment: (a) Tensile Test Specimens, (b) Universal Machine, (c) Flammability Test Specimens, (d) Flammability Test Equipment.

Considering the product design specification and material flammability, the conceptual design of the roof is drafted. The embodiment and detail designs of the roof are then determined by utilizing the mechanical properties of the test results. The last step involves trial production of the solid thin corrugated roofing sheets from UPVC material using the extrusion injection machine in a manufacturing plant at Tangerang, Indonesia.

\section{DESIGN OF THE UPVC THIN CORRUGATED ROOFING SHEET}

The main formula of the roofing sheets material consists of $100 \%$ wt. PVC resin, $50 \%$ wt. Calcium $\left.\mathrm{Carbonate}_{(\mathrm{CaCO}}\right)$ filler combined with some small parts of additives and pigment. Tensile and flammability properties of the UPVC sample are summarized in Table 1.

Table 1: Tensile and Flammability Tests of the UPVC Sample

\begin{tabular}{|c|l|c|}
\hline No. & \multicolumn{1}{|c|}{ Properties } & Value \\
\hline 1 & Flammability (UL 94) & $\mathrm{V}_{\mathrm{O}}$ \\
\hline 2 & Tensile strength $\left(\sigma_{\mathrm{b}}\right)$ and elongation at break $(\epsilon)$ & $27.3 \pm 2.5 \mathrm{MPa}$ and $20 \%$ \\
\hline 3 & Modulus of elasticity & $2,960 \pm 160 \mathrm{MPa}$ \\
\hline
\end{tabular}

The PDS of a UPVC thin corrugated roofing sheet is described as below:

- $\quad$ The corrugated roofing sheets must not transmit sunlight.

- Ability to reflect most of the sunlight.

- The material must be fire retardant and more economical than the GFRP composite material and also corrosion resistant.

- Able to accommodate very high rainfall $350 \mathrm{~mm} / \mathrm{h}$ and can be installed up to the roof slope of 5 degrees.

- Able to withstand an installer-man, wind lift force, and a combination of wind and rain loads at the same time between $1.2 \mathrm{~m}$ purlins distance.

The conceptual design of the UPVC thin corrugated roofing sheet is arranged based on a combination of all subfunctions listed in Table 2. The results of the combination of all sub-functions will form an overall function that meets the PDS. There will be many variants of solution, so priorities need to be ranked based on technical and economic considerations. The first ranked option is considered as the first priority which will lead to the chosen conceptual design. 
Table 2: Sub-Functions of the UPVC Thin Corrugated Roofing Sheet

\begin{tabular}{|c|l|l|l|l|}
\hline \multirow{2}{*}{ No. } & \multicolumn{1}{|c|}{ Sub-Function } & \multicolumn{3}{c|}{ Solution Alternatives } \\
\cline { 3 - 5 } & \multicolumn{1}{|c|}{$\mathbf{1}^{\text {st }}$ Solution } & \multicolumn{1}{c|}{$\mathbf{2}^{\text {nd }}$ Solution } & \multicolumn{1}{|c|}{$\mathbf{3}^{\text {rd }}$ Solution } \\
\hline 1 & No transmission of the sunlight & $\begin{array}{l}\text { Solid roofing } \\
\text { sheet }\end{array}$ & $\begin{array}{l}\text { Hollow roofing } \\
\text { sheet }\end{array}$ & - \\
\hline 2 & Reflects most of the sunlight & Light grey color & Dark grey color & White color \\
\hline 3 & $\begin{array}{l}\text { Better fire retardant and more economical than GFRP } \\
\text { and also corrosion resistant }\end{array}$ & UPVC material & CPVC material & $\begin{array}{l}\text { Mortar } \\
\text { composite }\end{array}$ \\
\hline 4 & Ability to flow heavy rainwater at a low slope roof & $\begin{array}{l}\text { Trimdek } \\
\text { corrugation }\end{array}$ & $\begin{array}{l}\text { Integrity } \\
\text { corrugation }\end{array}$ & - \\
\hline
\end{tabular}

There are many variants of conceptual design that are a combination of the first to fourth sub-function solutions. These variants include,

- $\quad 1^{\text {st }}$ conceptual design: $1.1-2.1-3.1-4.1$.

- $\quad 2^{\text {nd }}$ conceptual design: $1.1-2.2-3.1-4.1$.

- $\quad 3^{\text {rd }}$ conceptual design: $1.1-2.1-3.2-4.1$.

- $4^{\text {th }}$ conceptual design: $1.1-2.1-3.1-4.2$.

- $5^{\text {th }}$ conceptual design: $1.2-2.1-3.1-4.1$, and so on.

Conceptual design is determined by assessing each alternative solution based on technical and economic considerations. The first conceptual design variant was chosen. Solid roofing sheet is preferred over hollow roofing sheet because the roof production is easier and the amount of mass is lighter, so it is more economical [17]. Light grey roof color is preferred than dark grey because it reflects more sunlight [18-20]. Meanwhile, if the selected white color will cause the possibility of light transmission. This condition is undesirable. The material properties for blocking sunlight can be fulfilled by adding more white pigment. This will cause the cost of raw materials to be less economical. CPVC material was not chosen because it is more expensive than UPVC. Also, mortar was not chosen because it can be easily broken and heavy [4-6]. UPVC material was chosen because it is sufficient to provide physical-mechanical properties as a roof structure, as shown from the result of tensile test and the price is quite economical [16, 17]. Also, UL 94 test result shows that the flammability of UPVC ( $V_{O}$ class) is better than GFRP (HB class). Trimdek and Integrity profiles, both have a large capacity to accommodate rainwater with a low roof slope [25]. Trimdek's profile was chosen because it has five crests instead of than four in Integrity profile. The fasteners of Trimdek's profile is more regular than Integrity profile where it is on the left and right sides and in the middle of the crests. Based on this description, the selected conceptual design should be the solid roofing sheet from UPVC material with color of light grey and the corrugated profile is Trimdek. The thickness chosen is $1.5 \mathrm{~mm}$.

The embodiment design of the cross section of the UPVC thin corrugated roofing sheet is shown in Figure 2. The profile contains five crests and four valleys. The effective width is $765 \mathrm{~mm}$, the crest height is $29 \mathrm{~mm}$ and the roof thickness is $1.5 \mathrm{~mm}$. According to Lysaght [25] this Trimdek profile is able to flow heavy rainwater up to $400 \mathrm{~mm} / \mathrm{h}$ with a low slope of up to 5 degrees. 


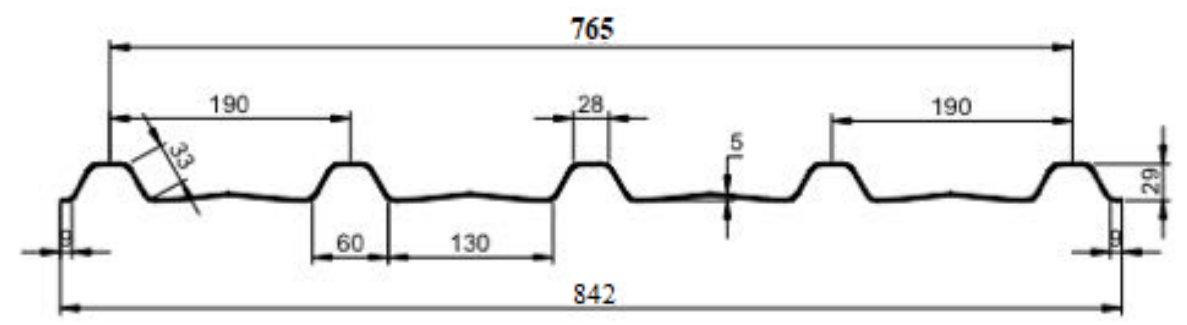

Figure 2: Cross Section of the UPVC Thin Corrugated Roofing Sheet.

The detailed design contains description about strength of the roof structure from the load that will occur.

\section{Data and Design Assumptions}

- $\quad$ Effective width of the one roofing sheet, $\mathrm{w}=765 \mathrm{~mm}=0.765 \mathrm{~m}$.

- Maximum distance between two purlins, $\mathrm{L}=1.2 \mathrm{~m}$.

- $\quad$ Mass of roof, $\mathrm{ma}=2.6 \mathrm{~kg} / \mathrm{m}^{2}=25.51 \mathrm{~N} / \mathrm{m}^{2} \rightarrow$ weight of roof, $\mathrm{Wa}=20 \mathrm{~N} / \mathrm{m}$.

- Weight of an installer-man is assumed $75 \mathrm{~kg} \rightarrow \mathrm{P}=736 \mathrm{~N}$.

- Load of rainwater is assumed $20 \mathrm{~kg} / \mathrm{m}^{2}=196.20 \mathrm{~N} / \mathrm{m}^{2} \rightarrow \mathrm{W}_{\mathrm{R}}=150 \mathrm{~N} / \mathrm{m}$.

- $\quad$ Load of wind is assumed $69.3 \mathrm{~kg} / \mathrm{m}^{2}=679.83 \mathrm{~N} / \mathrm{m}^{2} \rightarrow \mathrm{W}_{\mathrm{W}}=520 \mathrm{~N} / \mathrm{m}$.

- Both of the purlins are assumed as fixed-fixed support, so the maximum bending moment at the two support is $\mathrm{M}_{\max }=\left(\mathrm{wL}^{2} / 12\right)$ and the maximum deflection at the middle of the purlin span is $\delta=(\mathrm{w} \mathrm{L} / 384 \mathrm{EI})$.

\section{Technical Data and Loads}

- Inertia moment of the cross section of the Trimdek profile with thickness $1.5 \mathrm{~mm}$,

- $\quad \mathrm{Ix}=161,114 \mathrm{~mm} 4=0.161114 \times 10-6 \mathrm{~m} 4$

- Distance of the furthest point of the cross section from the neutral axis, $\mathrm{c}=19.21 \mathrm{~mm}=0.01921 \mathrm{~m}$.

- $\quad$ Height of the crest, $\mathrm{h}=29 \mathrm{~mm}=0.029 \mathrm{~m}$.

- Taken from the Table 1 , the tensile strength of the UPVC material, $\sigma b=25 \mathrm{MPa}=25 \times 106 \mathrm{~N} / \mathrm{m} 2$

- $\quad$ Taken from the Table 1 , modulus of elasticity, $\mathrm{E}=2,800 \mathrm{MPa}=2,800 \times 106 \mathrm{~N} / \mathrm{m} 2$

- $\quad$ Taken the punch shear strength, $\tau \mathrm{s}=15 \times 106 \mathrm{~N} / \mathrm{m} 2$

- The weight of an installer-man is assumed the middle of the span, $\mathrm{P}=736 \mathrm{~N}$.

- The distribution load of the roof weight, $w 1=20 \mathrm{~N} / \mathrm{m}$.

- The distribution load of the roof weight + rainwater load + wind speed force,

- $\quad \mathrm{w} 2=(20+150+520) \mathrm{N} / \mathrm{m}=690 \mathrm{~N} / \mathrm{m}$.

\section{Stress Analysis of the Roof Structure}

- (1) The normal stress from the load of an installer-man: 
- Maximum bending moment at the both fixed support,

- $\operatorname{Mmax}=(\mathrm{PL} / 8)+(\mathrm{w} 1 \mathrm{~L} 2 / 12)=(736 \times 1.2 / 8)+(20 \times 1.22 / 12)=112.8 \mathrm{Nm}$.

- Normal stress at the both fixed support,

- $\sigma=(\operatorname{Mmax} \mathrm{c} / \mathrm{I})=(112.8 \times 0.01921 / 0.161114 \times 10-6)=13.5 \times 106 \mathrm{~N} / \mathrm{m} 2=13.5 \mathrm{MPa}$

- $\quad<\sigma b=25 \mathrm{MPa} \rightarrow$ ok (the safety factor, $\mathrm{sf}=1.9$ ).

- (2) The normal stress from the combination of rainwater and wind force,

- $\quad$ Maximum bending moment at the both fixed support, Mmax =w2 L2 / $12=(690 \times 1.22 / 12)=82.8 \mathrm{Nm}$.

- Normal stress at the both fixed support,

- $\sigma=(\operatorname{Mmax} \mathrm{c} / \mathrm{I})=(82.8 \times 0.01921 / 0.161114 \times 10-6)=9.9 \times 106 \mathrm{~N} / \mathrm{m} 2=9.9 \mathrm{MPa}$

- $<\sigma b=25 \mathrm{MPa} \rightarrow$ ok (the safety factor, $\mathrm{sf}=2.5$ ).

- (3) The punch shear stress from the wind uplift,

- Area of the one roofing sheet on the $1.2 \mathrm{~m}$ between two purlins support, $\mathrm{A}=0.765 \times 1.2=0.918 \mathrm{~m} 2$

- $\quad$ Wind uplift force, $\mathrm{Fw}=\mathrm{Ww} \times \mathrm{A}=679.83 \times 0.918=624 \mathrm{~N}$.

- There are six screws fastener, but only four screws that are assumed fixed the roof from wind forced uplift. The punch shear stress,

- $\tau \mathrm{s}=\mathrm{Fw} / \mathrm{As} 1=(\mathrm{Fw}) /(4 \pi \mathrm{Dt})=\{(624) /[(4 \pi)(0.015)(0.0015)]\}=2.24 \mathrm{x} 106 \mathrm{~N} / \mathrm{m} 2<\tau \mathrm{s}=15 \times 106 \mathrm{~N} / \mathrm{m} 2 \rightarrow \mathrm{ok}$ (the safety factor, $\mathrm{sf}=6.7$ ).

\section{Deflection Analysis of the Roof Structure}

- The limit ratio between the maximum deflection and the span length is determined from the allowable strain $\epsilon$ max of $1 \%$, and so $\sigma=(\operatorname{Mmax})(\mathrm{c}) /(\mathrm{I})=\mathrm{E} \epsilon \max$

- $\quad(w 2$ L2 / 12) $(0.01921)=\mathrm{EI} \times 1 \times 10-2$

- $\quad \mathrm{w} 2=(12 \times 1 \times 10-2 \times \mathrm{EI}) /(0.01921 \mathrm{~L} 2)=6.24675 \mathrm{EI} / \mathrm{L} 2$

- $\delta=(\mathrm{w} 2 \mathrm{~L} 4 / 384 \mathrm{EI})=\{(6.24675 \mathrm{EI} \mathrm{L} 2) /(384 \mathrm{EI})\}=0.0162676 \mathrm{~L} 2$

- $\delta / \mathrm{L}=0.0162676 \mathrm{~L}=0.0162676 \times 1.2=0.01952=1 / 51$

- The maximum deflection at the middle span from the rainwater and the wind forces,

- $\delta=(\mathrm{w} 2 \mathrm{~L} 4 / 384 \mathrm{EI})=\{(690 \times 1.24) /(384 \times 2,800 \times 106 \times 0.161114 \times 10-6)\}=8.26 \times 10-3 \mathrm{~m}=8.26 \mathrm{~mm}$

- The ratio between the maximum deflection and the span length is,

- $\delta / \mathrm{L}=8.26 \times 10-3 \mathrm{~m} / 1.2 \mathrm{~m}=1 / 121<(1 / 51) \rightarrow \mathrm{ok}$

- The maximum deflection, $\delta=8.26 \mathrm{~mm}<$ crest height of $29 \mathrm{~mm} \rightarrow$ safe against the possibility of overflowing rainwater. 
The final design chosen is in the form of solid thin corrugated roofing sheet from UPVC material with Trimdek profile that clearly meets all PDS requirements. No light transmission and a good reflection of sunlight are fulfilled by the selection of the grey light color of UPVC material. This UPVC material is not only corrosion resistant, but also has better fire resistant and is cheaper than GFRP material. Its ability to discharge rainwater with high rainfall rate of $400 \mathrm{~mm} / \mathrm{h}$ at a low slope of 5 degree is fulfilled by Trimdek's profile. The cross section of Trimdek corrugated roof has an effective width of $765 \mathrm{~mm}$, peak height of $29 \mathrm{~mm}$ and thickness of $1.5 \mathrm{~mm}$ with five peaks and four valleys. The detailed design of the roof structure with the purlins distance of $1.2 \mathrm{~m}$ shows that the roof structure is able to withstand an installer-man, the combined force of rain and wind, and the exerting lift force from the wind. The designed roof has met the technical requirements equivalent to metal roofing sheet, but has the advantage of corrosion resistant and economic value. Thus, it has an excellent opportunity to fill the market needs in Indonesia.

\section{TRIAL PRODUCTION OF THE UPVC THIN CORRUGATED ROOFING SHEET}

The last step is the trial production of the solid thin corrugated roofing sheets from UPVC material using the extrusion injection machine in a manufacturing plant at Tangerang, Indonesia. Preparation of the production trial begins with preparing a mixture of raw materials which are mixed homogeneously. The chosen formula of the UPVC material consists of $100 \%$ wt. of PVC resin, $50 \%$ wt. of $\mathrm{CaCO}_{3}$ filler, and some small parts of additives and pigment. The homogeneous powder mixture of raw material is placed in a hopper. From the hopper, the raw material enters the heated barrel cylinder. The heat produces a temperature of around 218-225 degrees celsius which transform the raw material into a liquid phase. Inside the heated barrel cylinder, there is an extruder screw that serves to push the liquid material toward the injection nozzle. Liquid material is injected into the mould to produce a continuous plate sheet. The temperature of the slabs decreases with the additional distance travelled. Furthermore, the plate sheet which was still hot enough about 205 degrees celsius was formed by a set of Trimdek profile forming rollers. The profile sheet that is formed will continue to cool by a water chiller and solidify so that it forms a thin solid corrugated roofing sheet of Trimdek profile. The trial production of the UPVC thin corrugated roofing sheet is shown in Figure 3.

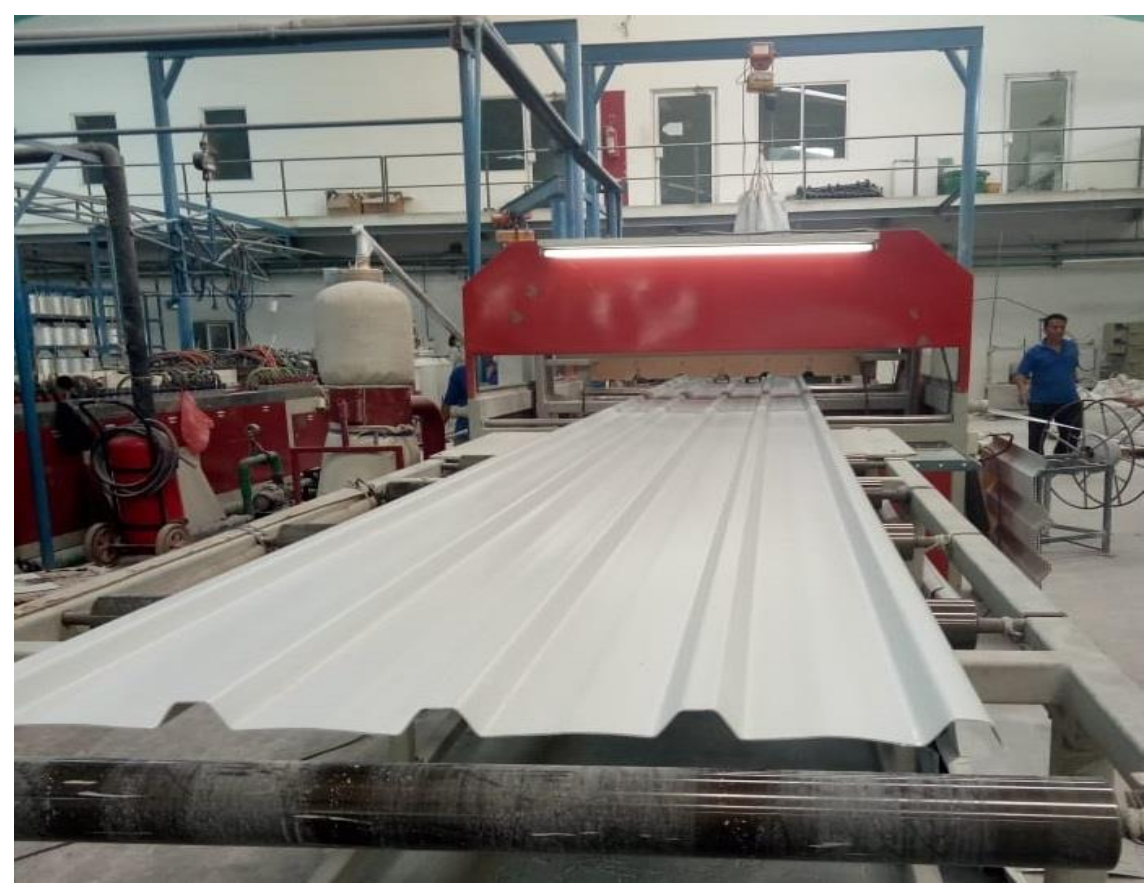

Figure 3: Trial Production of the UPVC Thin Corrugated Roofing Sheet. 


\section{CONCLUSIONS}

This paper describes the design of thin corrugated solid roofing sheets from UPVC material. The roof is designed for carrying loads of a man roof installer, a combination of wind and rain loads and wind uplift. The distance between the two roof support of purlins is designed at a distance of up to $1.2 \mathrm{~m}$.

The resulting design is a solid roofing sheet from UPVC material with light grey color. The roof will have Trimdek corrugated profile with five crests and four valleys with effective width of $765 \mathrm{~mm}$, crest height of $29 \mathrm{~mm}$ and thickness of $1.5 \mathrm{~mm}$. The Trimdek profile with a low slope of up to 5 degree is chosen since it is able forto flow heavy rainfall with a rate of up to $400 \mathrm{~mm} / \mathrm{h}$.

\section{ACKNOWLEDGEMENT}

Special thanks to Mr. Alex Hendro, President Director of PT Intec Persada-Indonesia, for allowing authors to use company facilities to conduct the research.

\section{REFERENCES}

1. Suvanjumrat, C. and Rugsaj, R. (2016). Lifetime estimation for metal sheet cladding and roofing in wang-noi combined cycle power plant. Engineering journal, Volume 20, Issue 2, 18 May 2016, 147-158.

2. Abdulkarim, B.I., Abdullah, Y.A. and Salam, K.A. (2009). Corrosion resistance of commercial roofing sheets to acid rainwater in Eleme, Rivers, Nigeria. International journal of ChemTech research, Volume 1, Issue 4, 2009, 802-806.

3. Khondker, Shirajom Monira, and Mehnaz Tabassum. "Kashinath Bhaban: A Unique Building of Panam Nagar Bears Testimony to Colonial Architecture in Bengal." International Journal of Civil Engineering (IJCE) 2.3 (2013): 97-108.

4. Oloruntoba, D.T., Oluwole, O.O. and Oguntade, E.O. (2009). Comparative study of corrosion behaviour of galvanized steel and coated Al 3103 roofing sheets in carbonate and chloride environments. Materials and design, Volume 30, Issue 4, April 2009, 1371-1376.

5. Janani, R., Kalyana Chakravarthy, P.R. and Ilango, T. (2018). Budget houses for low-income people. International journal of mechanical engineering and technology Volume 9, Issue 13, December, 109-117.

6. AL-AZHARI, WAEL W. "A STUDY OF HOUSING IDENTITY IN REFUGEE SETTLEMENTS IN JORDAN: AL-WAHDAT REFUGEE CAMP AS A CASE STUDY." Urban Studies (IJEEFUS) 2.3 (2012): 26-45.

7. Eswaramoorthi, P., Nandhakumar, P., Karthikeyan, S. and Magudeaswaran, P. (2017). Study on improvement in strength properties of corrugated roofing sheets with the addition of various fibres in the mortar. International journal of civil engineering and technology Volume 8, Issue 8, 463-471.

8. SHINDE, SAMBHAJI D., and V. P. Gaikwad. "Application of GIS for mapping rainwater harvesting potential: a case study of Nidhal village in Satara district, Maharashtra, India." International Journal of Research in Applied, Natural and Social Sciences 4.5 (2016): 141-148.

9. Dias, C.M.R., Campello, E.M.B., Savastano, H. Jr. and John, V.M. (2018). Exploratory pre-industrial test linking FGM and Hatschek technologies for the manufacture of asbestos-free corrugated cementitious roof sheets. Construction and building materials Volume 190, 30 November, 975-984.

10. Adeboye, ALBERT BABAJIDE. "Characteristics Of Modern Ecclesiastical Architecture In Nigeria: A Case Study Of Some Selected Church Buildings." International Journal of Research in Engineering \& Technology 3.1 (2015): 1-10. 
11. Delvasto, S., Toro, E.F., Perdomo, F. and de Gutierrez, R.M. (2010). An appropriate vacuum technology for manufacture of corrugated fique fiber reinforced cementitious sheets. Construction and building materials Vol. 24, Issue2, Feb., 187-192.

12. Ramakrishna, G., Sundararajan, T. and Kothandaraman, S. (2011). Strength of corrugations of a roofing sheet reinforced with sisal fibres. Journal of engineering and applied sciences Volume 6, Issue 12, December, 24-32.

13. Sivakumar, A., Dhanasekar, G., Madhumitha, L. and Parthiban, V. (2019). Strength of corrugation in roofing sheet with various fibres. International journal of engineering and advanced technology Volume 9, Issue 1, October, 309-313.

14. de Mello Innocentini, M.D., Vieira de Faria, M.A., Rosseto Crespi, M. and Batista Andrade, V.H. (2019). Air permeability assessment of corrugated fiber-cement roofing sheets. Cement and concrete composites Volume 97, March, 259-267.

15. Kfoury, A., Mitri, G., Arab, D., El Zakhem, H. and Aouad, G. (2019). Risk assessment of asbestos-cement roof sheets in Chekka, North Lebanon. Environmental monitoring and assessment Volume 191, Issue 6, 1 June, Article number 391.

16. Rao, P. S. and Husain, M.M. (2016). Prediction analysis on mechanical properties of hygrothermal ageing GFRP composite laminates. Indian Journal of Engineering \& Materials Sciences 23 (4), 288-296.

17. Zainudin, M., Diharjo, K., Kaavessina, M. and Setyanto, D. (2018. The properties degradation of exposed GFRP roof. AIP Conf. Proc. 1931. 030063.

18. Eskandari, N., Motahari, S., Atoufi, Z., Hashemi Motlagh, G. and Najafi, M. (2017). Thermal, mechanical, and acoustic properties of silica-aerogel/ UPVC composites. Journal of applied polymer science Volume 134, Issue 14, 10 April, Article number 44685 .

19. Setyanto, D. (2016). The possibility of E-glass woven roving as reinforcement of GFRP composite sheet roof. AIP Conf. Proc. 1717. 040007.

20. Janajreh, I., Alshrah, M. and Zamzam, S. (2015). Mechanical recycling of PVC plastic waste streams from cable industry: a case study. Sustainable cities and society Volume 18, 1 November, 13-20.

21. Setyanto, D. (2019). Design and FE modeling of UPVC corrugated hollow roofing sheet. MATEC Web of Conf. $258,01017$.

22. Kic, P. and Müller, M. (2019). Colour treatment of aluminium roof sheets, a significant operating factor. Manufacturing technology Volume 19, Issue 5, 780-785.

23. Yuan, J., Emura, K. and Farnham, C. (2016). Highly reflective roofing sheets installed on a school building to mitigate the urban heat island effect in Osaka. Sustainability (Switzerland) Volume 8, Issue 6, 27 May, Article number 514.

24. Uemoto, K. L., Sato, N.M.N. and John, V.M. (2010). Estimating thermal performance of cool colored paints. Energy and buildings Volume 42, Issue 1, January, 17-22.

25. Koshy, M. and Arul Jayachandran, S. (2018). Investigations on the wind uplift behaviour of standing seam cold formed steel roofing sheets. Journal of structural engineering Volume 44, Issue 6, February-March, 673-682.

26. Narayan, S. and Mathews, M.S. (2003). Behaviour of roofing sheet systems under static uplift loads. Journal of the institution of engineers (India): civil engineering division Volume 84, Issue 3, November, 216-222.

27. Narayanan, SP. and Mathews, M.S. (2014). Roofing sheets systems for industrial sheds in cyclone prone areas based on dynamic testing. Malaysian construction research journal Volume 14, Issue 1, 1 December, 63-78.

28. Narayanan, S.P. and Mathews, M.S. (2014). Roofing sheets systems for industrial sheds for different wind zones based on static load testing. Malaysian construction research journal Volume 14, Issue 1, 1 December, 79-96.

29. BlueScope Lysaght Limited (2008), Lysaght roofing \& walling users guide 2008-9 ed. 


\section{AUTHORS PROFILE}

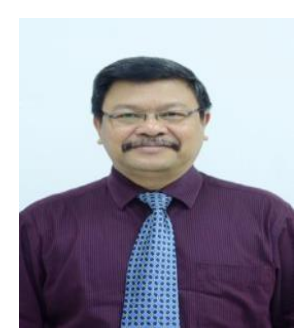

Djoko Setyanto received his Ph.D in Mechanical Engineering from Gadjah Mada University, Yogyakarta, Indonesia. He is currently serving as Researcher and Associate Professor at Department of Mechanical Engineering Atma Jaya Catholic University of Indonesia, Jakarta, Indonesia. He teaches a variety of Engineering units including Strength of Materials, Theoretical and Experimental Mechanics, Vibrations, Engineering Design, and Polymer Matrix Composites. He is also an industry practitioner in polymer materials roofing sheet manufacturing company at Tangerang-Indonesia as the leader of a product development research team. His main research interests deal with the experimental mechanics, engineering product development, and polymer/ polymer matrix composites.

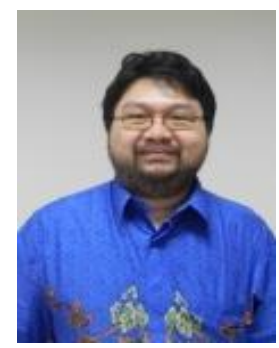

Arka Dwinanda Soewono received his Ph.D in Mechanical Engineering from The University of British Columbia, Canada, and is currently working as Researcher and Assistant Professor at Department of Mechanical Engineering Atma Jaya Catholic University of Indonesia, Jakarta, Indonesia. He teaches a variety of engineering topics including Thermodynamics, Fluid Mechanics, Engineering Measurement Techniques, and Research Methodology and Experimental Design Plan. His main research interests are focused on the development of internal combustion engine, particulate emission measurement, and alternative renewable energy sources, and engineering product development.

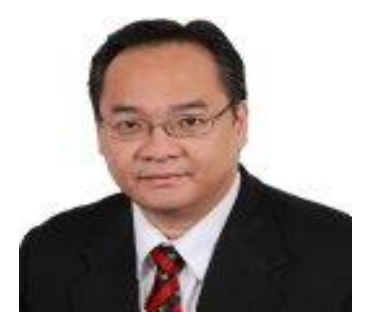

Widodo Widjaja basuki received his Ph.D in Mechanical Engineering from Karlsruhe Institute Technology in Germany, and is currently working as Researcher and Assistant Professor at Department of Mechanical Engineering Atma Jaya Catholic University of Indonesia, Jakarta, Indonesia. He teaches a variety of engineering topics including Engineering Materials, Selection and Life Cycles of Materials, welding process metallurgy, and Engineering Chemistry. His main research interests are focused on the development of materials engineering and engineering product development. 